\title{
The use of protein hydrolysate improves the protein intestinal absorption in undernourished mice infected with Schistosoma mansoni
}

\author{
O uso de hidrolisado protéico aumenta a absorção intestinal de proteínas \\ em camundongos desnutridos e infectados com Schistosoma mansoni
}

Eridan M. Coutinho', Haroldo S. Ferreira², Monica L. Assunção², Sandra L. Carvalho', Sheilla A. Oliveira ${ }^{1}$ and Andréa A. Francelino²

\begin{abstract}
Patients residing in endemic areas for schistosomiasis in Brazil are usually undernourished and when they develop the hepatosplenic clinical form of the disease should usually receive hospital care, many of them being in need of nutritional rehabilitation before specific treatment can be undertaken. In the mouse model, investigations carried out in our laboratory detected a reduced aminoacid uptake in undernourished animals which is aggravated by a superimposed infection with Schistosoma mansoni. However, in well-nourished infected mice no dysfunction occurs. In this study, we tried to improve the absorptive intestinal performance of undernourished mice infected with S. mansoni by feeding them with hydrolysed casein instead of whole casein. The values obtained for the coefficient of protein intestinal absorption (cpia) among well-nourished mice were above $90 \%$ (either hydrolysed or whole protein). In undernourished infected mice, however, the cpia improved significantly after feeding them with hydrolysed casein, animals reaching values close to those obtained in wellnourished infected mice.
\end{abstract}

Key-words: Undernutrition. Schistosomiasis mansoni. Casein hydrolysate. Intestinal protein absorption.

Resumo Portadores de esquistossomose mansônica no Brasil são quase sempre desnutridos e, ao desenvolverem a forma hepatoesplênica da doença, geralmente necessitam de atenção hospitalar. Sob tais circunstâncias seria interessante uma reabilitação nutricional prévia ou paralela ao tratamento específico. Investigações conduzidas em nossos Laboratórios, utilizando camundongos, detectaram redução da absorção protéica entre animais desnutridos, a qual foi agravada por uma infecção superposta com Schistosoma mansoni. Contudo, em camundongos infectados, porém bem nutridos, tal disfunção não foi observada. Objetivou-se avaliar a absorção intestinal de camundongos desnutridos e infectados pelo S. mansoni, alimentados com caseína hidrolisada em comparação com caseína integral. Os resultados obtidos para o Coeficiente de Absorção Intestinal de Proteínas entre os camundongos bem nutridos foram superiores a 90\% (tanto HID como INT). Entre os animais desnutridos, contudo, o aumentou significativamente quando se utilizou o hidrolisado protéico, atingindo valores muito próximos daqueles obtidos pelos camundongos infectados e alimentados com a dieta controle.

Palavras-chaves: Desnutrição. Esquistossomose mansônica. Hidrolisado protéico. Absorção intestinal de proteína.

\footnotetext{
1. Centro de Pesquisas Aggeu Magalhães da Fundação Oswaldo Cruz, Recife, PE. 2. Departamento de Nutrição do Centro de Ciências da Saúde da Universidade Federal de Alagoas, Maceió, AL, Brasil.

Financial support: from the UNDP/World Bank/WHO Special Programme for Research and Training in Tropical Diseases (TDR), Conselho Nacional de Desenvolvimento Científico e Tecnológico (CNPq), Fundação de Amparo à Pesquisa do Estado de Alagoas (FAPEAL), Fundação Oswaldo Cruz (FIOCRUZ) and Universidade Federal de Alagoas (UFAL) - Brazil.

Address to: Prof. Haroldo S. Ferreira. Av. Des. Almeida Guimarães 37, Pajuçara, 57030-160 Maceió, AL, Brasil.

Fax: 55 82-214-1665.

e-mail: haroldo@ fapeal.br, www.nutricaobasica.cjb.ne

Recebido para publicação em 17/7/2001.
} 
Patients residing in endemic areas for schistosomiasis are usually undernourished ${ }^{23}$. Such patients when they develop severe clinical forms of the disease should receive hospital care and many of them are given special diets to improve their nutritional status before specific treatment can be established. Usually some dietetic formulae are given to the patients including those utilized in liver cirrhosis, but none take into consideration the singular liver and intestinal lesions related to schistosomiasis mansoni, in which the anatomical and pathophysiological pictures differ from those seen in other diseases. Previous investigations have detected both protein and lipid malabsorption in undernutrition 1214152225 and schistosomiasis 47891011181920 .

According to investigations by this laboratory ${ }^{4}$, protein malabsorption occurs in undernourished mice and is aggravated when there is a superimposed infection with S. mansoni. However, well nourished infected mice fed control diets have no dysfunction. Of the factors involved in the pathogenesis of schistosomiasis and its course to the hepatosplenic clinical form, the parasite burden is considered to be the most important ${ }^{2}$. For this reason, the effects of two different cercarial burdens were examined in the present study.

Although the occurrence of protein malabsorption was demonstrated in undernourished infected mice ${ }^{4} 9$, the cause of this dysfunction could not be determined. Enzyme deficiency was probably the main factor responsible.

This investigation was designed: 1) to evaluate whether a protein hydrolysate based diet (through its aminoacid component) would be better absorbed than a whole protein diet; and 2) to examine the effects of the intensity of infection upon the ability of malnourished infected mice to digest and absorb either dietetic whole protein or hydrolysed protein.

\section{MATERIAL AND METHODS}

Animals. Male Swiss weaning (21 to 25 days old) albino mice, weighing 10 to $15 \mathrm{~g}$ were kept in individual cages under standardized conditions of light and temperature.

Infection. Infection was made by the percutaneous route with cercariae of the SL Brazilian strain of Schistosoma mansoni recently shed from Biomphalaria glabrata raised in our laboratory.

Diets. A control diet (CONT) was prepared to supply all the nutritional needs of mice ${ }^{21}$, containing $22.6 \%$ protein (Table 1). The experimental diet (EXP) had a low protein content $(5.2 \%)$ and all the components of the control diet, starch replacing the removed protein. For the absorption tests, diets Test 1 and Test 2 were prepared, the composition of which was the same as diets CONT and EXP, respectively, except for the substitution of whole casein by hydrolysed casein (N-ZCase Plus, Sigma N4642). Diets were prepared in pellet form.

Experimental groups. A batch of 221 mice was initially formed. Only 152 animals survived until the end of the investigation due to spontaneous mortality induced by schistosomiasis infection and/or undernutrition. They were distributed into six groups, according to the type of the ingested diet (CONT or EXP) and to the cercarial burden (mice free of infection, infected with 40 cercariae, infected with 80 cercariae) as shown in Table 2.

Table 1 - Composition of the control diet (proteins, carboidrates, fat and vitamins water solubre and fat solubre).

\begin{tabular}{|c|c|c|c|c|c|c|c|c|}
\hline \multirow[b]{2}{*}{ Ingredients } & \multirow[b]{2}{*}{$\mathrm{g} \%$} & \multicolumn{6}{|c|}{ Percentage composition } & \multirow[b]{2}{*}{ fiber } \\
\hline & & prot & carb & fat & $\min$ & water soluble vits & fat soluble vits & \\
\hline Casein & 27.1 & 22.0 & - & - & - & - & - & - \\
\hline Corn starch & 57.4 & 0.6 & 50.4 & 0.1 & 0.1 & - & - & - \\
\hline Soybean oil & 7.5 & - & - & 7.5 & - & - & - & - \\
\hline Mineral mixture ${ }^{1}$ & 4.0 & - & - & - & 4.0 & - & - & - \\
\hline Water soluble vits ${ }^{2}$ & 1.0 & - & - & - & - & 1,0 & - & - \\
\hline Fat soluble vits ${ }^{3}$ & 1.0 & - & - & 1.0 & - & - & 1.0 & - \\
\hline Cellulose & 2.0 & - & - & - & - & - & - & 2.0 \\
\hline Total & 100.0 & 22.6 & 50.4 & 8.6 & 4.1 & 1.0 & 1.0 & 2.0 \\
\hline
\end{tabular}

1. Mineral mixture. $\mathrm{CaCO}_{3}: 600 \mathrm{~g} ; \mathrm{K}_{2} \mathrm{HPO}_{4}: 645 \mathrm{~g}$; CaHPO $2 \mathrm{H}_{2} 0: 150 \mathrm{~g} ; \mathrm{NaCl}: 335 \mathrm{~g} ; \mathrm{MgSO}_{4} 7 \mathrm{H}_{2} 0: 204 \mathrm{~g} ;$ citrate Fe: $20 \mathrm{~g} ; \mathrm{MnSO}: 10 \mathrm{~g} ; \mathrm{ZnCl}: 1.5 \mathrm{~g} ; \mathrm{CuSO}$ : $1.0 \mathrm{~g} ; \mathrm{KI}: 0.2 \mathrm{~g} ; \mathrm{CoCl}_{2}: 0.05 \mathrm{~g} ; \mathrm{KAl}\left(\mathrm{SO}_{4}\right)_{2}: 0.1 \mathrm{~g} ; \mathrm{Na}_{2} \mathrm{SeO}_{3}: 0.01 \mathrm{~g} ; \mathrm{NaF}: 0.2 \mathrm{~g}$. 2. Water soluble vitamins: choline $\mathrm{HCl}$ : $10 \mathrm{~g} ;$ para-aminobenzoic acid: $5 \mathrm{~g} ;$ inositol: $1 \mathrm{~g}$; nicotinic acid: $0.5 \mathrm{~g}$; calcium pantothenate: $0.25 \mathrm{~g}$; riboflavine: $0.25 \mathrm{~g}$; thiamine $\mathrm{HCl}: 0.20 \mathrm{~g}$; pyridoxine $\mathrm{HCl}: 0.05 \mathrm{~g}$; folic acid: $0.05 \mathrm{~g}$; biotin: $0.01 \mathrm{~g}$, vitamin B12: 0.0005g; corn starch: q.s.p. 300g. 3. Fat soluble vitamins: retinol: 45,000mg; vitamin D2: 750mg; dl-alpha-tocopherol: 5,000mg; vitamin K: 5 mg; corn starch: q.s.p $100 \mathrm{~g}$

Soon after weaning, three groups were fed with CONT diet and three others were offered EXP diet. Diets CONT and EXP were used throughout the investigation except for the last five days of the trial, when the CONT diet was replaced by Test 1 diet. Test 2 diet followed the use of the EXP diet for the respective group of mice.
Food and water were given ad libitum: after adaptation for a period of three days, subgroups of at least 10 mice on each diet were: a) infected with 40 or b) 80 cercariae of $S$. mansoni, and a third subgroup was kept free of infection. All the animals were weighed on a weekly basis. 
Table 2 - Mortality rates in undernourished and well-fed mice, regarding Schistosoma mansoni infection and cercarial burden.

\begin{tabular}{lcccc}
\hline & \multicolumn{4}{c}{ Mice $\left(\mathrm{n}^{\circ}\right)$} \\
\cline { 2 - 4 } Experimental groups & $\begin{array}{c}\text { at the beginning of } \\
\text { the experiment }\end{array}$ & $\begin{array}{c}\text { spontaneous } \\
\text { mortality }\end{array}$ & $\begin{array}{c}\text { sacrificed at the end } \\
\text { of the experiment }\end{array}$ & $\begin{array}{c}\text { mortality rates } \\
(\%)\end{array}$ \\
\hline Prot 22.6\% (non-infected) & 28 & 2 & 36 & $7.1^{\mathrm{a}}$ \\
Prot 22.6\% (40 cercariae) & 54 & 19 & 23 & $35.2^{\mathrm{b}}$ \\
Prot 22.6\% (80 cercariae) & 40 & 17 & 30 & $42.5^{\mathrm{b}}$ \\
Prot 5.2\% (non-infected) & 33 & 3 & 15 & $9.1^{\mathrm{a}}$ \\
Prot 5.2\% (40 cercariae) & 24 & 9 & 23 & $37.5^{\mathrm{b}}$ \\
Prot 5.2\% (80 cercariae) & 42 & 19 & 152 & $45.2^{\mathrm{b}}$ \\
\hline Total & 221 & 69 & 31.2
\end{tabular}

$a ; b$ indicate significant differences $(p<0.05)$ regarding values in the last column (Chi-square test)

Whole protein intestinal absorption (Phase P1): this assay was performed by calculating the Protein Absorption Coefficient, according to the following formula:

Protein absorption coefficient $=\frac{\text { nitrogen intake }- \text { fecal nitrogen }}{\text { nitrogen intake }} \chi 100$

Mice were kept in individual stainless steel metabolic cages and the underlying trays were covered with a sheet of filter paper to absorb the urine and minimize faecal contamination with urinary nitrogen. For three consecutive days, the food intake was determined for each mouse in each group and the feces were collected for nitrogen determination. The assay started soon after the $20^{\text {th }}$ week of infection. All the nitrogen determinations (diets and feces) were made through the Kjedahl's micromethod $^{13}$. Faecal markers were considered to be unnecessary under the conditions of the present investigation.

Protein hydrolysate intestinal absorption (Phase P2): after the first assay (Phase P1) was completed, the same mice were submitted to phase $\mathrm{P} 2$, receiving Test 1 or Test 2 diets, both containing hydrolysed casein in the same levels as whole casein in diets CONT and EXP, respectively. After two days of adaptation, the same schedule was used as in the first assay, in order to evaluate the intestinal absorption of this protein formula by the mice.

Calculations regarding faecal metabolic nitrogen were not taken into account, since previous investigation using the same experimental model had shown a high equivalence between apparent and true intestinal protein absorption ${ }^{9}$. Thus, for the objectives of this study, its influence was assumed to be negligible on the outcome results.

Ethics: All the procedures followed were in accordance with the FIOCRUZ's (Oswaldo Cruz Foundation - Brazil) guidance for the care and use of laboratory animals.

Statistical analysis: Differences between the groups were determined through analysis of variance and Duncan's test ${ }^{17}$. Student's " $t$ " test for paired samples was also used to compare $\mathrm{P} 1$ and $\mathrm{P} 2$ phases of the intestinal protein absorption test. Differences in mortality rates were determined by Chi-square test. The probability level considered significant was $p<0.05$.

\section{RESULTS}

Weight curves. The weight curves of mice fed both CONT and EXP diets are shown in Figure 1. It can be easily noticed that the highest values are seen in the groups fed $22.6 \%$ protein. Infection with S. mansoni did not seem to have a notable influence on the weight of mice except from the $13^{\text {th }}$ week of the infection period onward, when infected sub-groups ingesting the lowprotein diet EXP (5.2\% protein) had an apparent better performance as compared with the non-infected ones ingesting the same diet $(p<0.05)$.

Protein intestinal absorption. The biological assays for determination of protein intestinal absorption showed that among the control groups (well nourished mice) the protein absorption coefficients were practically the same, independent of the protein source (either hydrolysed or whole protein). However, in the undernourished groups of animals, a difference could be detected between the two chemical formulae of dietetic protein, mice showing a better performance when fed with hydrolysed casein, reaching values very close to those displayed by mice fed the control $(22.6 \%$ protein) diet (Table 3).

Pathology. As can be observed in Figure 1, undernourished infected mice showed a higher weight gain as compared to undernourished non-infected ones from the $13^{\text {th }}$ until the $19^{\text {th }}$ week of infection, with a trend to decline in the last week of the experiment. At the moment of necropsy, enlargement of the liver and spleen as well as presence of ascites were common gross findings.

Infected well-fed mice had similar findings regarding gross pathology, but in infected undernourished animals ascites seemed to be more severe.

Concerning the aspect of the intestinal content, in a few animals, a slight degree of diarrhea was detected 


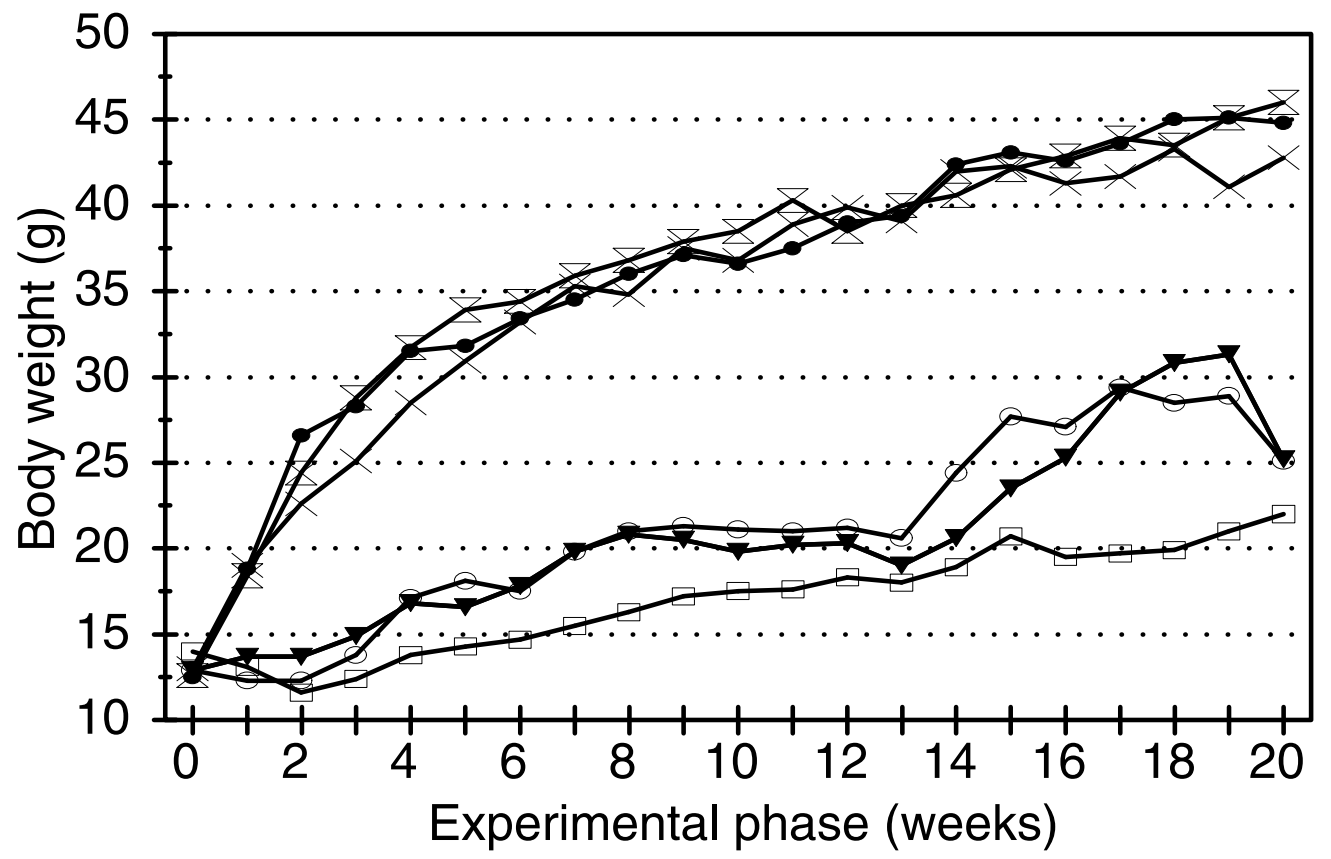

$$
\begin{aligned}
& * 22.6 \text { non-inf } \varangle 22.6 \inf 40 \rightarrow 22.6 \inf 80 \\
& \leftarrow 5.2 \text { non-inf } \rightarrow 5.2 \inf 40 \rightarrow 5.2 \inf 80
\end{aligned}
$$

Figure 1 - Weight curves of mice by type of diet and cercarial load (S. mansoni).

Legend: 22.6 or 5.2 : refers to control (22.6\% protein) or experimental (5.2\% protein) diets; non-inf $=$ mice tree of infection; 40 or $80=$ experimental groups infected with 40 or 80 cercariae of S. mansoni, respectively.

Table 3 - Coefficient of protein intestinal absorption in mice fed either whole or hydrolysed casein diets, infected with different cercarial

\begin{tabular}{|c|c|c|c|c|c|c|c|c|c|c|}
\hline \multirow[b]{2}{*}{ Experimental groups } & \multirow[b]{2}{*}{$\mathrm{N}$} & \multicolumn{4}{|c|}{ Whole protein } & \multicolumn{4}{|c|}{ Hydrolysed protein } & \multirow[b]{2}{*}{$\mathrm{p}$-value } \\
\hline & & $\mathrm{N}$ ing & $\mathrm{N}$ exc & $\mathrm{N}$ abs & CPIA & $\mathrm{N}$ ing & $\mathrm{Nexc}$ & $\mathrm{N}$ abs & CPIA & \\
\hline Prot $22.6 \%$ (non-infected) & 26 & 0.7573 & 0.0674 & 0.6899 & $91.1 \pm 3.56^{(a)}$ & 0.6750 & 0.0513 & 0.6237 & $92.4 \pm 3.08^{(a)}$ & NS \\
\hline Prot $22.6 \%$ (40 cercariae) & 35 & 0.9873 & 0.0701 & 0.9172 & $92.9 \pm 4.96^{(a)}$ & 0.6506 & 0.0514 & 0.5992 & $92.1 \pm 3.88^{(\mathrm{a})}$ & NS \\
\hline Prot $22.6 \%$ (80 cercariae) & 23 & 0.6211 & 0.0590 & 0.5621 & $90.5 \pm 2.84^{(a)}$ & 0.4354 & 0.0431 & 0.3923 & $90.1 \pm 3.80^{(a)}$ & NS \\
\hline Prot 5.2\% (non-infected) & 30 & 0.0762 & 0.0163 & 0.0599 & $78.6 \pm 8.54^{(b)}$ & 0.1263 & 0.0120 & 0.1143 & $90.5 \pm 11.13^{(a)}$ & s \\
\hline Prot $5.2 \%$ (40 cercariae) & 15 & 0.1018 & 0.0172 & 0.0846 & $83.1 \pm 6.09^{(b)}$ & 0.1195 & 0.0153 & 0.1042 & $87.2 \pm 3.94^{(\mathrm{a})}$ & $\mathrm{s}$ \\
\hline Prot $5.2 \%$ (80 cercariae) & 23 & 0.0828 & 0.0188 & 0.0640 & $77.3 \pm 10.6^{(b)}$ & 0.0954 & 0.0166 & 0.0788 & $82.6 \pm 5.03^{(c)}$ & $\mathrm{s}$ \\
\hline
\end{tabular}
burdens.

$\mathrm{N}$ = nitrogen; ing = ingested; exc = excreted; abs = absorbed.

$a, b, c$ indicate significant differences $(p<0.05)$ regarding values in each column for CPIA (Duncan's test).

p-value: (Student's " $t$ " test for paired samples, regarding values for CPIA in the same line).

NS = non-significant; $\mathrm{S}$ = significant. 
during the first month of the experiment, faeces of normal aspect having been observed afterward.

Mortality rates. Mortality rates did not differ significantly between undernourished and well-fed mice, deaths being mainly due to $S$. mansoni infection. The apparent differences on account of cercarial burdens in the groups of undernourished and well-fed mice were not statistically significant (Table 2).

\section{DISCUSSION}

The influence of the diet was quite evident, low-protein fed mice showing the lowest values regarding body weight curves. However, schistosomiasis infection did not seem to influence the animals' growth under the conditions of this experiment, except from the $13^{\text {th }}$ week of infection onward, when infected subgroups in spite of ingesting the low-protein diet EXP (5.2\% protein) showed higher weight gains than non-infected ones ingesting the same diet $(p<0.05)$. This was likely due to the development of ascites, portal hypertension and hepatosplenomegaly observed by us and several authors in the chronic stage of murine schistosomiasis ${ }^{16}$. In addition, the detection of low levels of serum albumin has been reported by several investigators ${ }^{3}$ not only as a result of protein malnutrition but also due to some degree of hepatic derangement occurring during schistosome infection.

The biological assay performed in this investigation aimed to measure the amount of absorbed nitrogen in the intestine of undernourished and well-fed mice after ingesting two different protein formulae.

The use of faecal markers was considered to be unnecessary, because the animals ingested the same diets (CONT or EXP) all over the study except for the last five days of the experiment, including a two-day period for adaptation to diets Test 1 and Test 2, before data collection was initiated. The methodology used in this work had been previously described by Waterlow \& Wills ${ }^{26}$, Holemans \& Lambrechts ${ }^{12}$, among other investigators.

The data obtained in this investigation concerning protein absorption appear to conflict in some ways with previous results from our laboratory ${ }^{4}$. However, in past experiments, only the acute phase of murine schistosomiasis (nine weeks of infection) was studied; while the present investigation had been extended to the chronic phase of the disease (20 weeks of infection). In addition, in past investigations undernutrition was induced in mice by offering a human diet from endemic areas of Northeast Brazil (Regional Basic Diet - RBD), which is multideficient as well as having a low protein content ${ }^{24}$. In this study, a casein based diet was selected at levels of $5.2 \%$ (low-protein) and $22.6 \%$ (normalprotein). The undernutrition in the experimental model using the RBD was more severe than in the pure casein induced model, because the casein diets used have a higher biological value and also were supplemented with vitamins and minerals not utilized in the RBD induced model of murine undernutrition ${ }^{5}$.

In previous studies ${ }^{4}$, infection did not affect protein intestinal absorption in well nourished mice, but it aggravated malabsorption detected among undernourished animals. In the present investigation, however, the reduced absorption was related only to undernutrition. Mice in the RBD model absorbed about $40 \%$ of the ingested protein and in the casein model they absorbed around $80 \%$.

When instead of dietary whole protein the animals started being fed a protein hydrolysate, undernourished infected animals exhibited absorption rates close to the control mice, except for those with very heavy schistosomal infections (80 cercariae), although they presented a significant improvement in their absorptive performance.

These results suggest that the reduced protein intestinal absorption detected in malnourished animals is probably related to decreased protein hydrolysis ${ }^{1525}$, since administration of hydrolysed protein was able to improve significantly the absorption rates of undernourished mice. Information is lacking regarding the quantity and composition of the pancreatic juice in undernourished infected mice. It is known that in murine schistosomiasis pancreatic damage is frequently seen and may be particularly severe in some cases ${ }^{16}$.

The infective cercarial load seemed to interfere in some way with the absorption of protein hydrolysate, except in well-nourished hosts. Undernourished mice infected with the heaviest cercarial load (80 cercariae) improved considerably absorption while on hydrolysed casein although they did not reach the same absorption rates detected for well-nourished animals. However, undernourished mice either non-infected or infected with 40 cercariae attained values close to those of well-nourished infected controls.

In spite of the favourable results, data reported here were only based on short-term experiments in laboratory animals, further studies being necessary before the use of protein hydrolysates can be recommended as an auxiliary dietetic formula in the treatment of patients with schistosomiasis.

\section{REFERENCES}

1. Cheever AW, Warren KS. Hepatic blood flow in mice with acute hepatic-splenic schistosomiasis mansoni. Transactions of the Royal Society of Tropical Medicine and Hygiene 58:406-412, 1964.

2. Coutinho A. Fatores relacionados com o desenvolvimento das formas clínicas da esquistossomose mansônica. Revista da Associação Médica Brasileira 25:185-188, 1979.
3. Coutinho EM, Abath FGC, Freitas LPCG, Salzano AC, Lapa MA, Campos FS, Melo EB. Liver and serum soluble protein changes and pathomorphology in undernourished mice with acute schistosomiasis mansoni. Revista da Sociedade Brasileira de Medicina Tropical 24:235-243, 1991. 
4. Coutinho EM, Ferreira HS, Freitas LPCG, Silva MR, Cavalcanti CL, Samico MJA. Nutrition and acute schistosomiasis. Memórias do Instituto Oswaldo Cruz 87: 297-301, 1992.

5. Coutinho EM, Freitas LPCG, Abath FGC. The influence of the Regional Basic Diet from Northeast Brazil on health and nutritional conditions of mice infected with Schistosoma mansoni. Revista da Sociedade Brasileira de Medicina Tropical 25:13-20, 1992.

6. DeWitt WB, Warren KS. Hepatosplenic schistosomiasis in mice. American Journal of Tropical Medicine \& Hygiene 8:440-446,1959.

7. Domingo EO, Warren KS. Pathophysiology of the small intestine in murine Schistosomiasis mansoni including a review of the literature. Gastroenterology 56:231-240, 1969.

8. El-Rooby A, Gad El Mawla N, Galii N, Abdalla A, Shakir M. Studies on the malabsorption syndrome among Egyptians. II Malabsorption in bilharzial hepatic fibrosis. Journal of Egypt Medical Association 46:777-782, 1963.

9. Ferreira HS, Coutinho EM, Teodósio NR, Cavalcanti CL, Samico MJA. Intestinal protein absorption in malnourished mice with acute schistosomiasis mansoni. Memórias do Instituto Oswaldo Cruz 88:581-587, 1993.

10. Fikry ME. Disturbances of digestion and absorption in bilharzial hepatic fibrosis. Journal of Tropical Medicine and Hygiene 66:213-215, 1963.

11. Fikry ME, Hanno MG, El-Sayed M, Dorry K. The iodo 131 triolein intestinal absorption test in shistozomal (bilharzial) hepatic fibrosis patients. Acta Gastroenterology Belgian 29: 99-104, 1966.

12. Holemans $\mathrm{K}$, Lambrechts $A$. Nitrogen metabolism and fat absorption in malnutrition and in kwashiorkor. Journal of Nutrition 56:477-494, 1955.

13. Horwitz W. Official Methods of Analysis of the Association of Official Analytical Chemists (AOAC). $3^{\text {rd }}$ edition Washington, DC, 1975.

14. James WPT. Intestinal absorption in protein-calorie malnutrition. Lancet 1:333-339, 1968

15. Kirsch RE. Aminoacid transport in experimental protein-calorie malnutrition. American Journal of Clinical Nutrition 21:1302-1305, 1968.
16. Lenzi HL, Lenzi JA, Rosman FC. Pancreatic involvement in murine schistosomiasis. Brazilian Journal of Medical Biology Research 22:1105-1109, 1989.

17. Montgomery DC. Design and Analysis of Experiments. John Wiley \& Sons, New York, 1991.

18. Mott CB, Neves DP, Bettarello A. Absorção intestinal na forma hepatoesplênica da esquistossomose mansônica. Revista do Hospital das Clínicas da Faculdade de Medicina de São Paulo 26: 55-60, 1971.

19. Nigro SP, Miszputen S, Saad FA. Estudo morfométrico da mucosa jejunal na esquistossomose mansônica humana. Revista da Associação Médica Brasileira 30: 61-63, 1984.

20. Pucci H, Vilela MP, Miszputen SJ, Carvalho N, Secaf F, Saad FA. Estudo da absorção intestinal de gorduras na esquistossomose mansônica humana. Revista da Associação Médica Brasileira 24:341-344, 1978.

21. Tagle MA, Donoso G. Net protein utilization determined in shortand long-term experiments with rats. Journal of Nutrition 87: 173178, 1965.

22. Tandon BN, Magotra ML, Saraya AK, Ramalingaswami V. Small intestine in protein malnutrition. American Journal of Clinical Nutrition 21: 813-819, 1968.

23. Tavares-ONeto J, Forleo-Neto E, Wilhelms Neto E, Prata A. Dados biométricos em esquistossomóticos adultos. Bahia - Brasil. Revista de Saúde Pública 22: 288-291, 1988.

24. Teodósio NR, Lago ES, Romani SAM, Guedes RCA. A Regional Basic Diet from Northeast Brazil as a dietary model of experimental malnutrition. Archivos Latinoamericano de Nutrición 40: 532-547, 1990.

25. Wapnir RA, Lifshitz F. Absorption of aminoacids in malnourished rats. Journal of Nutrition 104: 843-849, 1974.

26. Waterlow JC, Wills VG. Balance studies in malnourished Jamaican infants. 1 - Absorption and retention of nitrogen and phosphorus. British Journal of Nutrition 14:183-198, 1960. 